\title{
Farming practice, ecological temporality and urban communities at a Late Iron Age oppidum
}

Agriculture is a vital component of social practice, yet it is often overlooked as a key aspect in the social organisation of the communities resident at urban settlements. This paper uses the example of Late Iron Age oppida, a type of settlement at the intersection of the Iron Age and Roman worlds where research has focussed upon elites rather than community. Drawing upon studies of human-plant relationships, particularly that of ecological temporalities, this paper shows that considering the capacity of plants to affect people through 'planty agency' renders annual rhythms of human-plant relationships perceptible. The utilisation of archaeobotanical data in this novel way provides new insights into social practices and the formation of communities at Late Iron Age oppida.

Key words: oppida, plant agency, ecological temporality, Late Iron Age

Author: Lisa Lodwick, University of Oxford

Email: lisa.lodwick@all-souls.ox.ac.uk 


\section{Introduction}

The oppida of later Iron Age/early Roman western Europe remain an enigmatic form of settlement that do not conform to typical categorisations of urban centres. As a group of sites where debate continues over the practice of agricultural activities and the organisation of the resident social group, oppida provide a fruitful case study to explore how the temporalities of plant-human relationships affect social identities. Agriculture often features in the study of urbanisation processes, through resource centralisation or shifts in production categories (Styring et al., 2017ab), or as one of several criteria (Smith, 2016). Such approaches are often applied to urban sites in Mesopotamia and the Mediterranean which have formed the core of archaeological debates on urbanism. Rarely, though, is the practice of agriculture seen as an important factor in the social organisation of urban, in contrast to, rural communities (Bogaard et al., 2011). Over the last decade, the categorisation and development of oppida, a heterogeneous group of settlements stretching from southern Britain to central Europe from the 2nd century BC to 1st century AD, has been subject to fresh debate (Fernández-Götz, 2014; Moore, 2017a). One thread of this has been the proposition that oppida can be characterised as low-density agglomerations (Moore, 2017b), linked to the interpretation of enclosures within oppida as evidence for an agricultural household-based society (Moore, 2017a). This article seeks to address calls to provide insights into oppida communities by studying agriculture as a social practice.

In order to advance such an investigation, a body of work on plant-human relationships within social geography will be drawn upon, to trace ecological temporalities at the site of Silchester (Calleva Atrebatum) in central-southern Britain. Agricultural practice has been accorded a key role in the formulation of social structures during the Iron Age (c. 600BC-AD 43). Land tenure and farming are seen as having a major role in social structure, be it through the maintenance of communities, engagement with long distance gift exchange, or providing the food for communal feasting (Giles, 2007; Hill, 2011). In contrast, agricultural practices in the Roman period (c. AD43-410) have been attributed little significance in the articulation of social identities and the formation of communities (Taylor, 2013). The absence of consideration of farming practice as a contributing factor to social relations at oppida can be linked in part to the continued evaluation of oppida within classical Mediterranean models of urbanisation (Stoddart, 2017), where farming activities did not occur in Greek or Roman cities.

Plant agriculture is of interest in this study as the annual cycle of sowing, tending and harvesting provides insights on temporal rhythms of social practice, which cannot be traced through material culture (Gardner, 2012). It is contended here that plant-based activities have been lacking from previous social practice approaches due to their low visibility in the archaeological record. Without an articulation of the distinctive ways in which plant agency acts upon humans through farming practice, and a consideration of how this can be studied through the archaeological record, the study of plant agriculture as a social practice and hence contributing factor to social organisation cannot be advanced.

This paper aims to interpret archaeobotanical data from late Iron Age oppida through the lens of 'plant agency', drawing specifically on the notions of ecological temporality as recently formulated by Brice (2014). The social groupings resident at oppida in the late Iron Age of southern Britain have remained elusive, with a focus on elites and little understanding of how late Iron Age communities worked (Hill, 2011). Recent large-scale excavations within a residential area of the oppidum at Silchester, Insula IX (Fulford et al., 2018), provide a substantial archaeobotanical dataset enables the ecological temporality of human-plant relationships to be reconstructed, enabling the consideration of issues of labour and time, which provide new perspectives on late Iron Age communities. 


\section{Communities in the Late Iron Age oppida}

The later Iron Age of southern Britain (c. 100 BC-AD 43) was a period of major social change, with new forms of technology, settlement, burials, and kingship (Hill, 1995). The emergence of territorial oppida, enclosed oppida, and poly-focal settlements (Cunliffe, 1976; Moore, 2012) shows a new social reality for some of the population of south-eastern Britain. Whilst the terminology is much debated, oppida have shared characteristics of places of assembly, elite residence, ritual activities and extensive enclosures (Haselgrove 2000; Pitts 2010). The territorial oppida, among which Silchester (later a Roman town, Calleva Atrebatum) is generally counted, feature discontinuous earthworks, areas of multiple activity foci, burial and craft working (Haselgrove 2000, Haselgrove and Millett 1997).

Explanatory priority in narratives of oppida development has previously been attributed to continental immigrants and prestige gift exchange networks (Cunliffe, 1976; Haselgrove, 1982). The heavy critique of these exogenous models, on the basis of small amounts of foreign material culture (Fitzpatrick 2001) and explanatory weakness has seen a move towards internal factors (Hill, 2007). In recent years, research has pursued the landscape context of oppida, long term population movements and shifts in value systems (Hill, 2007; Sharples, 2010).

A contrasting line of research has explored the nature of individual political connections between late Iron Age rulers and Rome, especially the articulation of the power of obsides through coinage (Creighton 2000). Despite the move towards internal factors, research continues to focus on the elites - identifying who they were (Creighton, 2000), and how power was maintained through activities within the landscape, such as ritual, feasting and wall construction (Bryant, 2007; Creighton, 2006; Fernández-Götz, 2014). The social organisation of the communities resident at these new settlement types often remains at the margins of study with focus instead placed on the origin of people, for instance in northern Gaul (Fulford and Timby, 2000: 564; Pitts and Perring, 2006).

Explicit study of social organisation of oppida communities beyond their leaders is rare. Drawing on evidence from King Harry Lane cemetery, Verulamium, clusters of graves were interpreted as representing discrete social units, decreasing in size over time as daily activities took precedence over kinship as the key factor for structuring society (Haselgrove and Millett, 1997). Hill (2007: 28) has suggested that the presence of wealthy burials in Kent and south Anglia indicates the development of more distinct groupings based around a household unit. Regarding the oppida of Northern France, Haselgrove (2007) has recognised the presence of a caste system, based on evidence of internal settlement division and craft specialisation. Attention to the presence of internal settlement division has been raised recently by a number of authors, with examples given of Villeneuve St-Germain and Condé-sur-Suippe (Collis, 2000: 234; Fernández-Götz, 2018: 141; Moore, 2017a). The presence of oppidum-wide communities has also been highlighted, maintained for instance by the construction of enclosures through shared labour and the provision of open areas for ritual and political activities (Fernández-Götz, 2014; Moore, 2017a). The acknowledgment of the role of agricultural activities within oppida as part of the phenomenon of low-density urbanism (Moore, 2017b) provokes a consideration of agricultural activities as another line of evidence for social organisation.

\section{The social role of farming in Iron Age and Roman Britain}

Iron Age farming can be characterised as developed mixed agriculture, where the main crops were spelt wheat, emmer wheat and barley, and the animals were cattle, sheep, and pig. There are both indications of specialist agricultural settlements, such as banjo enclosures (Moore, 2012), and the storage of agricultural resources at hillforts and other sites through the presence 
of above ground storage structures, and subterranean storage pits (Cunliffe, 2005). The major social changes of the late Iron Age in south-east Britain appear to have limited parallels in the evidence for agricultural practice. Agricultural innovations of spring-sowing and mono-cropping have been identified in a region of upland chalk downlands around Danebury hillfort, and at Silchester, hay-meadow management and flax cultivation began in the decades around the Roman conquest (Campbell and Hamilton, 2000; Lodwick, 2017a).

Major changes in the organisation of agriculture are instead evidenced after the Claudian conquest of AD43, with a proliferation of forms of farming settlements, corn-drying ovens, and an increasing reliance on cattle and spelt wheat (Lodwick, 2017b). Changes are mainly described in economic terms, classified as periods of intensification, innovation and expansion, often in relation to regional or empire wide events. This narrative of agricultural change has been constructed from archaeobotanical and zooarchaeological studies taking place from the late 1970s onwards. Yet, the utilisation of the now substantial datasets has focussed upon the identification of broad chronological trends, and the specialist economic role of different site types (Albarella, 2007; Stevens, 2003), rather than more nuanced site-based social practices.

This is despite more recent calls to study farming as a social practice in order to inform upon social identities. Such approaches have been clearly articulated for pastoral farming; for example - drawing on Ingolds's work on taskscapes - Chadwick $(2004,2016)$ has seen the movement of people and animals around enclosures and along trackways as meaningful activities for the creation of individual and group identities. Chadwick has touched upon aspects of arable farming, such as manuring, and animal and crop interaction, but not specified any examples or suggested how these could be studied.

In calling for a consideration of agricultural practice as a key factor in the rural societies of Roman Britain, Taylor (2013) has suggested such complementary areas of study as land tenure, animal husbandry and the construction of enclosures, but utilises only archaeological examples of regional pottery and metalwork distribution. The use of artefactual evidence for reconstructing agricultural practice is limited as many tools had multiple functions (Rees, 2011), and are too rare to be used to inform upon practice-based approaches, in contrast to artefacts associated with grooming and dress accessories (Eckardt, 2015). Practice-orientated approaches to plant remains themselves have remained lacking, at least for this period and region.

Whilst arable farming practices have not been studied through a practice-based approach, they do certainly have this potential. They are activities which can be studied at a range of resolutions using a range of evidence forms (cf. Gardner 2002: 329). Ethnographic fieldwork of communities still practicing unmechanised farming has shown the routine activities undertaken every year to cultivate cereal crops, such as weeding, sowing, harvesting etc. are consistent across regions, largely as these processes are governed by the physical properties of cereal plants (Hillman 1981). Furthermore, we know that a community of people who farm together can be considered as a meaningful social unit. For instance, observations from ethnographic studies of Sudanese farmers, show that that 'A person who does not farm may be liked... but cannot be a villager' (Baumann 1986: 149). The application of social practice to archaeological assemblage has largely been through material culture, building on Gardner's conceptualisation of practice emerging at the intersection of materiality and human agency (Gardner, 2007: 51). By bringing the material aspects of plants to the fore, practices involving them, namely plantbased farming activities, should become more tangible.

Whilst relational approaches in archaeology commonly consider material culture and more recently animals (Chadwick, 2016), plants have played a limited role in such discussions. This 
may well be due to the theoretical backgrounding of plants across academic disciplines (Head and Atchison, 2009; Jones and Cloke, 2008), arguably attributed to the western world view of plants as a lower form of life to humans and animals (Hall, 2011). However, various strands of research, principally within geography and anthropology, have revealed the particular agency of plants in influencing aspects of human life such as temporality, labour patterns and emotions. Crucially, the acknowledgement that plant agency emerges in the context of temporal human action and is revealed through material changes in plant bodies (Brice, 2014), provides a way forward for exploring the agency of plants in the past. Here archaeobotanical evidence is prioritised for providing the most direct links with human-plant relationships.

\section{Farming time, framing time}

In order to advance the study of arable farming as a social practice through the recognition of plant agency, the concept of ecological temporality which draws on the effects of plants on humans in structuring time, will be here advanced. An understanding of the farming year is a theme drawn upon within prehistoric archaeology. In considering evidence for agricultural activities in the Danebury environs landscape, Campbell correlated different archaeological evidence for agricultural activity with seasons, such as threshing waste indicating August and September, hazelnut shell with collecting wild plants in Autumn, and bracken with bedding for the over-wintering of animals (Campbell and Hamilton, 2000: 57-59). Inspired by Murphy (1977), and drawing upon medieval farming texts (Slicher van Bath, 1963) the study suggested the time of year in which sites were occupied (Figure 1), in this case seasonal occupation at the banjo enclosure at Nettlebank Copse (Campbell, 2000: 57). The notions of seasonal farming cycles have been further discussed by Jones. In reflecting upon seasonal activities at Danebury, he used pit capacity and medieval evidence for the faming year to estimate the annual timing of feasts (Jones, 2007). These interpretations have two key limitations: first, they draw on medieval texts, whose applicability to the Iron Age is unclear at best. Second, the interpretation is within economic discussions of labour scheduling, rather than incorporating other aspects of plant-human engagement into a more nuanced discussion of the affective experience of seasonal labour. 


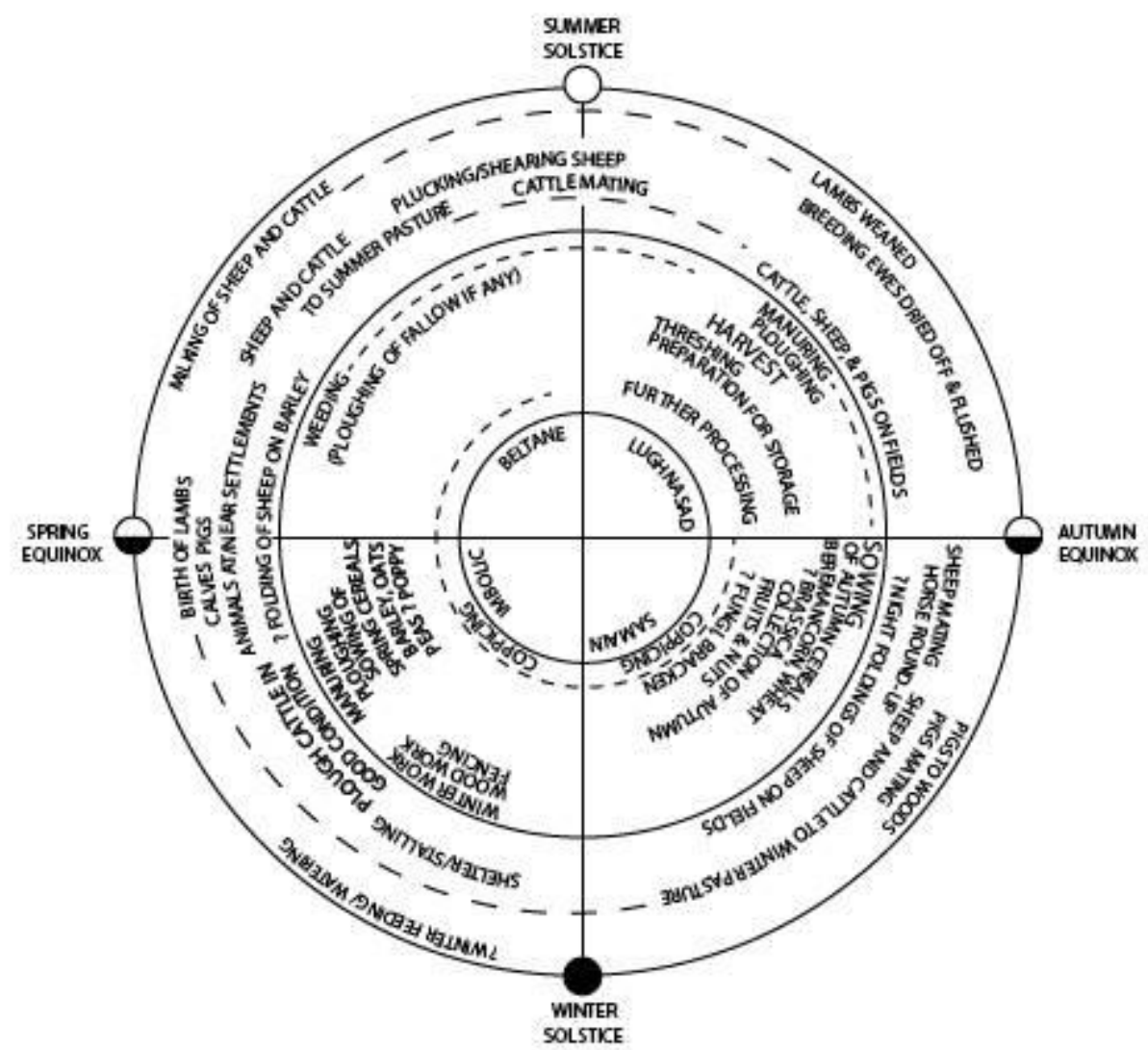

: The Iron

Figure 1: The Iron Age Age farming year, following Campbell 2000, Fig 3.10 (Reproduced with author's permission).

Beyond reconstructing the annual year, plants have also been incorporated into more explicit discussions of temporality - that is, the experience of time passing as both rhythmic and irreversible (Gardner, 2012). In the context of the Mesolithic-Neolithic transition in Britain, Garrow (2010) has used the presence of charred emmer grains to argue for a degree of permanence in a settlement, on the basis of the need to protect growing cereals from pests, and to regularly weed fields. The metaphor of arable farming has also been demonstrated as of key importance in the physical and cognitive world throughout later prehistory, with the annual cycle of farming being a key aspect. The significance of this temporality of farming is demonstrated through the agricultural loci for instances of structured deposition, such as in fields and wells, but also the deposition of cereal grains and tools. Of particular relevance here is the suggestion that larger houses in the later Iron Age drew on ideas of agricultural permanence to maintain their own power (Williams, 2003: 244).

Experiences of time would have changed dramatically from the Iron Age to Roman period of Britain, with a move from ecological or cyclical time to clock or linear time (Gardner, 2012: 158$160)$. In the former, time would have been reckoned in relation to natural features and crops (Brice, 2014: 948). In the latter, time was institutionalised by the Roman state, albeit the adoption of the Julian calendar was gradual, and likely to have co-existed alongside local ways of time-reckoning (Swift, 2002). For instance, the function of the enigmatic Roman-period dodecahedral objects has been interpreted as measurement of the angle of the sun in order to establish the agricultural calendar, such as the time of sowing (Van Driel Murray, 2002: 98). Whilst the Roman calendar was not widely imposed, imperialism also had much wider effects on time experiences via exchange and consumption (Gardner, 2002). Whilst shifts in the temporalities of exchange and consumption were taking place at late Iron Age oppida, 
interactions with plants through agriculture would still have been one of the major contributors towards experiences of temporality.

There have been limited explorations of temporality in late Iron Age and Roman Britain, with the exception of Gardner (2012). Gardner advanced beyond the long-standing division between cyclical and linear time by using Adam's concepts of time-frame, timing, and temporality to explore how practices of eating, dressing, exchange and deposition show the impact of the Roman empire on everyday temporalities. It is contended here that temporality can be studied additionally through reconstructing agricultural practices through archaeological plant remains to establish how plants act upon humans in annual cycles of cultivation.

\section{Planty Agency and Ecological Temporality}

There is clearly scope for a reconsideration of both the social organisation of communities at oppida, and, the role of plants in the negotiation of arable farming as a meaningful social practice. Before a study of the temporal aspect of agriculture can advance, the role of plants in mediating human action must first be explored. The clearest articulation of relational approaches to plants has been through the advancement of plant materiality (Van der Veen, 2014). Several scenarios are described whereby the entanglement of humans and plants is traced, for instance through the co-evolution of crops and weeds during domestication, and the routine engagement of farming practices. Van der Veen considers the impact of summer crops such as cotton, rice and banana to seasonal labour practices in Islamic North Africa and the Middle East. However, it is important to move beyond a broad consideration of agricultural systems to consider the 'planty agency' or effectiveness of specific crops on individuals.

The growing body of work on plant agency, primarily in the field of human geography, provides insights into the myriad ways in which plants can act upon people, be it through gardens, invasive species, or crop plants (Head and Atchison, 2009; Head et al., 2015). Here, agency is conceived of in the Latourian sense of having a capacity to affect, though with an acknowledgment that definitions of 'agency' within the material or ontological turn in archaeology remain debated (e.g. Ribeiro, 2016). The broad acceptance that plants have the capacity to act upon people has been crystallised in the concept of plant capacities, whereby a detailed consideration of plants was advanced through distinctive materialities, independent movement, sensing and communication, and flexibility of shape (Head et al., 2015).

Jones and Cloke (2008: 82) have argued that non-human agency must be studied "within its own ecological time-scales as well as in its own places". Archaeological work has begun to undertake such temporal considerations of plants, the best example being Taylor's approach to Mesolithic Yorkshire, by considering the annual rhythms of plants recorded in palaeoenvironmental studies around Lake Flixton, and the impact of this upon the structuring of human activities (Taylor, 2018).

Work within social geography by Brice has more fully illuminated the ecological temporalities of plant-crop interactions. Following Ingold (2000), Brice (2014: 947) argues that humans attune movement to changes in the environment, and that material changes in crop plants, such as texture or appearance, render the agency of plants perceptible. A way to take into account plant agency is through the concept of ecological temporality, whereby rather than separating natural- and clock-time, the temporality of farming activities is considered to be co-fabricated through interactions between plants and humans (Brice, 2014: 948). Brice applies these ideas to an ethnographic study of Australian vineyards. By following the growing year of grapes through interviews and observations, Brice observed changes in the plants' appearance, such as smell, taste, and colour, which induced emotional reactions such as stress, anxiety and tension, and significantly, necessitated changes in labour organisation amongst the vineyard 
workers. It was through observing material changes in plants, such as the sugar content of grapes and the colour of the berries, that Brice (2014: 954) was able to observe 'planty agency' affecting vine-yard workers. Working from Jones (2011), rather than seeing ecological and clock time as separate, Brice conceptualises ecological temporality as a way to consider multiple enactment of time experienced through plant agencies arising through temporal human practices (2014).

By drawing on this example from human-geography of 'following' the plants throughout their growing cycle, we can both be receptive to the material aspects of plants, such as smell and colour throughout their growing cycle, but also take into account the flows of human energy through the process of agriculture. This avoids prioritising the materiality of the static final archaeobotanical evidence recovered from archaeological sites. The application of ecological temporalities to archaeobotanical evidence provides a new way to analyse the presence of certain cereals, evidence for how they were cultivated, and the occurrence of other collected plant resources. This analysis would be based on the physical characteristics of plants - rather than external interpretations of function or seasonality derived from historical sources. This in turn opens up a space to study the temporality of human-plant relationships within a society on the edge of the expanding Roman world and it's imperial notion of time.

However, assessing the relational agency of plants in modern societies is challenging even in contemporary society, being reliant upon interviews, lengthy periods of fieldwork, and close observation of living plants (Head et al., 2015). Here, the temporal aspects of plants, as affective of humans through plant materialities, will be explored through a focus on cultivated and wild plants encountered in agricultural practices, drawing on botanical and ethnobotanical sources of information concerning specific plants. By paying attention to the planty agencies of specific individual plants, the multiple interactions between plants and humans at Silchester will become visible (Brice, 2014: 951).

\section{Ecological temporality at Late Iron Age and Early Roman Silchester}

The ability to trace ecological temporality as experienced through farming practices is reliant on archaeological sites with high quality archaeobotanical datasets to allow the importance of plant resources to be assessed. Such an assemblage is available from Silchester, where largescale excavations within the north-east area of Insula IX have produced a substantial archaeobotanical dataset (Lodwick, 2018). Silchester is located in central-southern Britain, at the intersection of the Thames Valley and the Hampshire Chalk downlands (Figure 2). Late Iron Age occupation was located within a 32ha enclosure (Figure 3). The construction of a v-shaped ditch, dated to C. 10BC, was followed by a period of occupation characterised by several wells, enclosures and buildings C. 10BC-AD10/20. Further trackways, wells, and enclosures were constructed following the Claudian Invasion in AD43 (Fulford et al., 2018: 12-69). There is evidence for residential occupation within the Insula in the form of traces of several buildings, but the low density of material culture, along with geoarchaeological insights, indicate that occupation was not very intensive, leading to suggestions of seasonal changes in the population (Fulford et al., 2018). The origin and the character of the social group resident at Silchester is debated, as at other oppida in Britain. It has been argued that migrants from northern France may have been present, based on dietary evidence and ceramic assemblages (Fulford et al., 2018: 213, 381; Fulford and Timby, 2000: 564). Specifically, the presence of the kings of the Commian dynasty is evident from coins minted at Calleva (Creighton 2006). 


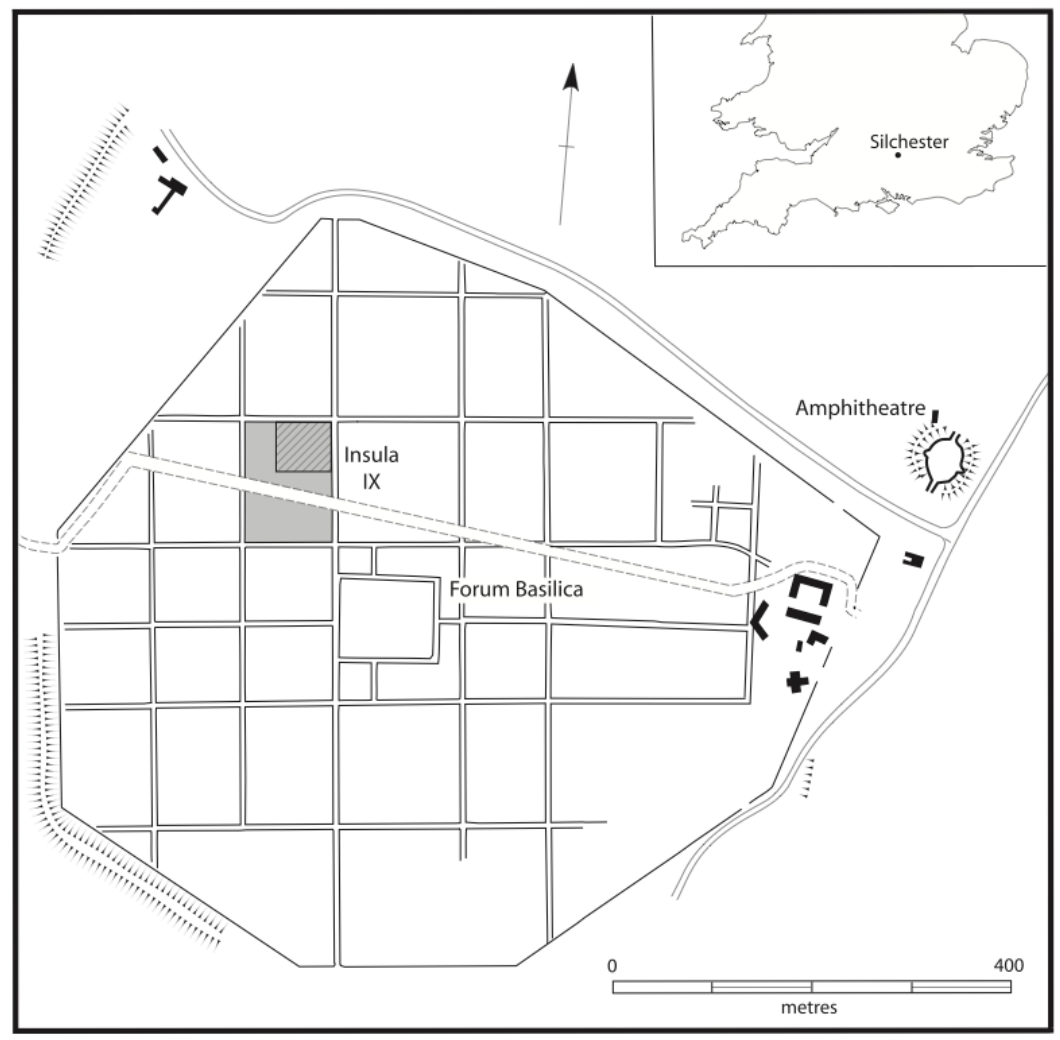

Figure 2: Plan of Roman Silchester showing the location of Silchester within central-southern Britain and the excavation area within Insula IX (Reproduced with permission, University of Reading).

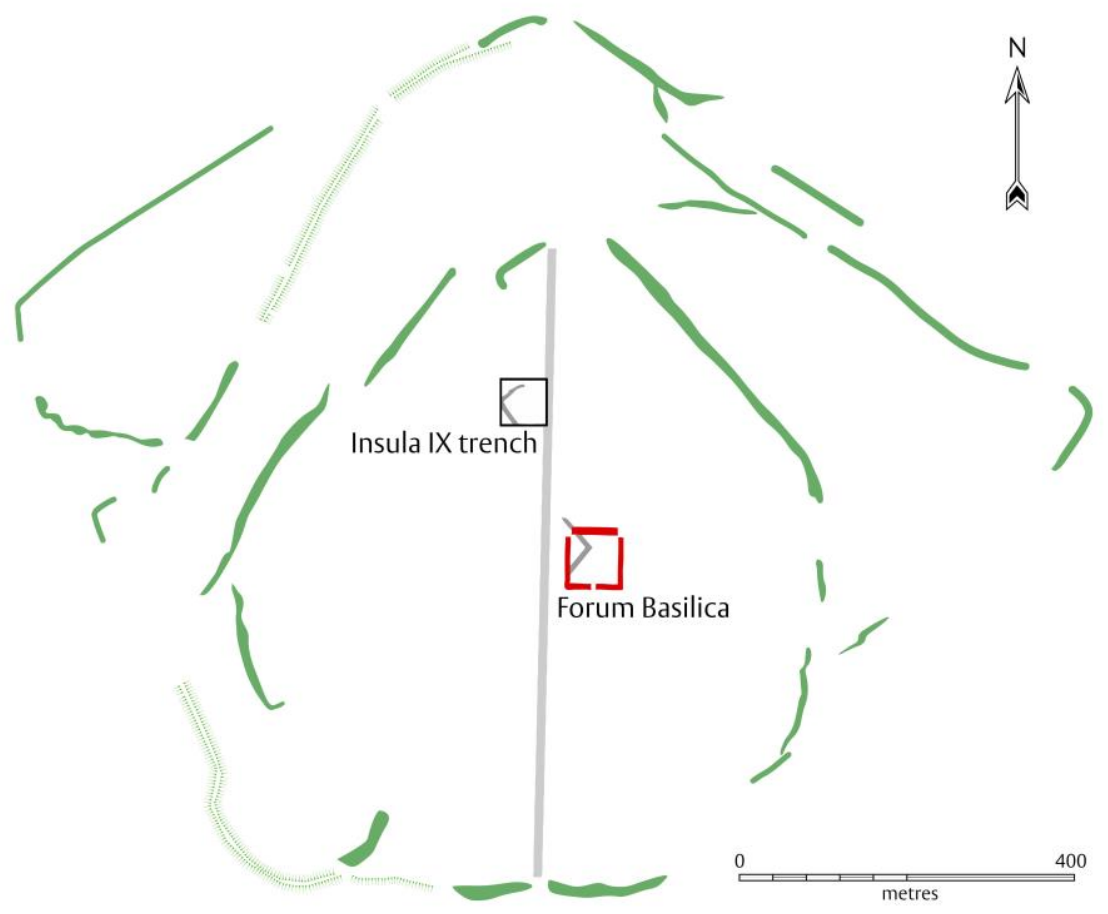

Figure 3: Plan of late Iron Age Silchester, showing the excavation site at Insula IX and the surrounding earthworks (Reproduced with permission, University of Reading). 
A substantial assemblage of charred and waterlogged plant remains have been studied from the late Iron Age (Period 0) and the early Roman occupation (Period 1), with a good spatial and chronological spread, enabling comparison in human-plant activities through time. A summary of key archaeobotanical findings is provided in Table 1, drawing upon the wider archaeobotanical report (Lodwick, 2017a, 2018) and the archived data-set (University of Reading, 2018).

Table 1: Summary of archaeobotanical results from Insula IX, Silchester.

\begin{tabular}{|l|l|l|}
\hline & $\begin{array}{l}\text { Period 0 Late Iron Age } \\
\text { c. 10 BC-AD 45/50 }\end{array}$ & $\begin{array}{l}\text { Period 1 Early Roman } \\
\text { c. AD 43-4-c. AD 80 }\end{array}$ \\
\hline Crop Choice & Spelt, six-row hulled barley, flax & Spelt, six-row hulled barley, flax \\
\hline Crop-Processing & $\begin{array}{l}\text { Fine-sieve spelt wheat by- } \\
\text { products }\end{array}$ & $\begin{array}{l}\text { Fine-sieve spelt wheat by- } \\
\text { products }\end{array}$ \\
\hline $\begin{array}{l}\text { Heathland } \\
\text { Resources }\end{array}$ & Bracken, gorse, heather & Bracken \\
\hline $\begin{array}{l}\text { Grassland } \\
\text { Resources }\end{array}$ & Hay & Hay \\
\hline
\end{tabular}
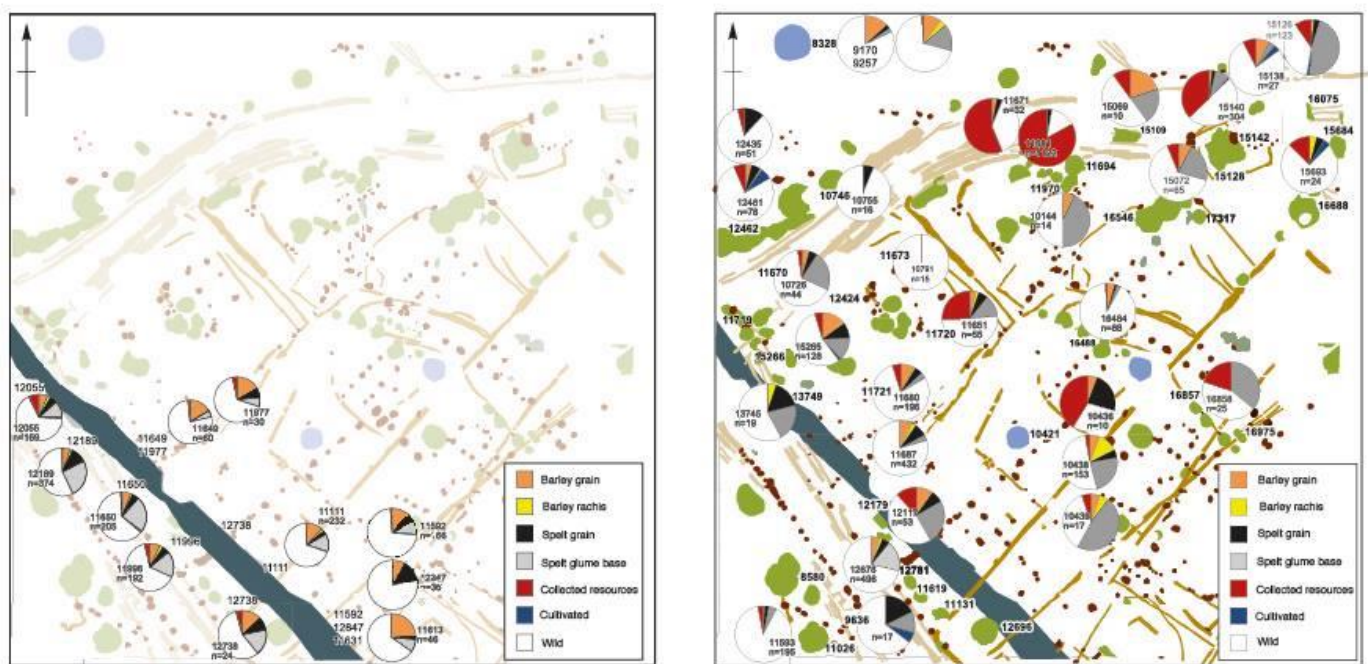

Figure 4: Composition of charred plant samples within Period 0 Insula IX after Lodwick, 2018, Fig 136 and 137 (left - ditch 11631, right - pits and wells) (Reproduced with permission, Society for the Promotion of Roman Studies).

The cultivation and processing of the staple-food source cereals would have constituted a major aspect of human-plant relationships. Samples from the across the settlement area contain charred spelt wheat glume bases and grains, and barley grain and rachis (Figure 4). Based on the proportions of chaff and grain we can infer that these represent the by-products of the finesieving from the final stages of spelt wheat cleaning (Hillman, 1981), and this activity must have occurred regularly in Periods 0 and 1. From the weed seeds present alongside the cereal remains, we know that the lifecycles of these plants, such as brome grass flowers in spring, indicated that the crops were autumn sown in soil of intermediate fertility (Lodwick, 2018), from which we can infer a harvest time in July. 
Spelt wheat, as a domestic cereal, is reliant on humans. It would need to be sowed into ploughed ground in the autumn, raked in, protected from bird attack and weeded throughout the growing season to ensure a productive harvest. As with Brice's vineyard workers, we see a shift in tempo from the monotonous task of weeding throughout winter and spring, with short days of labour, through to heightened activity at harvest time. The timing of harvest would have been marked largely by the change in the appearance of the wheat - a golden colour, and curling of the grain heads. Thus, the distinct characteristics of the cereal plant affected the seasonal patterns of human labour. The absence of spatial variation in the range of weed seeds recovered from the Insula implies that cultivation practices were similar in all households within the excavated area of Insula IX, implying shared practices undertaken in the fields. As spelt wheat is hulled, it would need to be transported back to the settlement, and dehusked further on a daily basis. We can infer that dehusking was undertaken on a small-scale, household basis due to the regular occurrence of cereal chaff but at a low-density (Lodwick, 2018: 291, 308).

A different type of crop was the oil plant, flax - Linum usitatissimum, an annual crop, cultivated for both oil and linen fibres. Flax was an important crop at Insula IX, with seeds and/or capsules occurring in $11 \%$ of late Iron Age and $45 \%$ of early Roman waterlogged samples, and occasionally in the charred assemblage. Flax is usually sown in the spring in Britain and grows to around $1 \mathrm{~m}$ tall with a branched head of tiny blue flowers. The crop is usually harvested soon after the petals have fallen, when the seed pods swell and turn golden, usually in August or early September (Bond and Hunter 1987). In order to anticipate the harvest of the flax crop, attention would have to be paid to visual changes in the appearance of flowers, and then changes in the size and colour of pods. The importance of visual observations of flax is stated by Pliny the Elder, who comments on the enlarging of fruits and the yellowing of plants (Pliny $\mathrm{NH}$ XIX, 25).

Pliny describes the multi-use processing of flax in the Roman world (Pliny NH XIX, 16-18), and the size range of flax seeds at Silchester implies an unspecialised crop (Lodwick, 2017a). The processing of flax for both fibres and oil crops is a labour-intensive process due to the physical characteristics of the flax plant. In order to release the seeds, capsules are usually pounded and then winnowed, followed by a series of stages to de-toxify the seeds (Ertuğ, 2010). The preparation of flax plants for linen fibres involves further stages whereby the stems are dewretted in fields or placed in retting pits, and close observation is required to ensure that fibres of the desired quality are obtained (Andresen and Karg, 2011).

It was not just crop plants which would have enacted their plant agency on people through material changes. Archaeobotanical data clearly shows the evidence for the collection of wild plants, with bracken fronds being abundant in late Iron Age and early Roman wells (Lodwick, $2017 a$ ). In period 0 , bracken occurs in $22 \%$ of waterlogged samples, and in period $1,25 \%$. These wells are distributed across the excavated area, implying that bracken was being collected and used by various residents, most likely as animal bedding (Mabey, 1996: 15-17; Rymer, 1976). Bracken is a fern, which today is a common plant on the heathlands around Silchester. The plants grow from rhizomes in the spring, maturing by July (Marrs and Watt, 2006). The timing of the bracken harvest is signalled by the fronds turning brown in Autumn (Rymer, 1976). The precise period when bracken would have required cutting was controlled by the interactions between the weather, soil, and the plant. The visual changes in bracken provide a strong seasonal structure to rural experiences (Mabey, 1996: 17).

The ecological temporality of human-plant interactions can also be considered through the management of grassland or hay meadows. Seeds and vegetative plant remains from a distinctive range of grassland vegetation, including Centaurea nigra - common knapweed and 
Rhinanthus minor - yellow rattle indicate the presence of a form of grassland community, produced through distinctive practices of hay meadow management (Lodwick, 2017a). These taxa co-occur in one Period 0 well, and, in around $50 \%$ of Period 1 samples across the Insula, providing good evidence for the management of grassland vegetation by the residents of the oppidum. The evidence from late Iron Age Silchester stands as the earliest for this practice in Britain (Lambrick and Robinson, 2009: 44-46).

The ecological temporality of this vegetation community can be reconstructed through modern accounts. The form of management specifically consists of the enclosure of areas of grassland in the early spring to prevent grazing and the harvest of the grass in July before the plants turn brown and seeds are shed (Greig, 1984), a stark contrast to the bright colours of hay meadow plants such as yellow ( $R$. minor), pink (Lychnis flos-cuculi), white (Filipendula ulmaria), and purple (Prunella vulgaris). Recently, this has been a two-day period in which the hay is cut, spread and turned to allow drying, before bundling and transport to the settlement (Hartley, 2012: 203). These activities have to be undertaken with great haste to avoid hay being spoiled, thus raising the tension and intensity of labour activities.

Complementary evidence from landscape studies in the hinterland of Late Iron Age Silchester indicates the presence of an animal enclosure to the south of the settlement (Creighton with Fry 2016, p 419) and Mid and Late Iron Age enclosures to the north and south-west of the oppidum (Fulford et al. 2017), demonstrating the presence of wider agricultural activity in the hinterland of the late Iron Age settlement.

Humans are able to choose how to grow and process each crop, but the mechanisms of doing so are usually limited, as shown by the similarity of cereal processing techniques. By the late Iron Age, societies in southern Britain were very much reliant on crop plants. Changes in the style of cultivation would have to be gradual or piecemeal, as the risk of harvest failure from year to year would be too great. Whilst humans always have the agency to choose which crops they work with, once these decisions have been made, plants have the capacity to affect humans through their material agency.

\section{Seasonal cycles of plants and people}

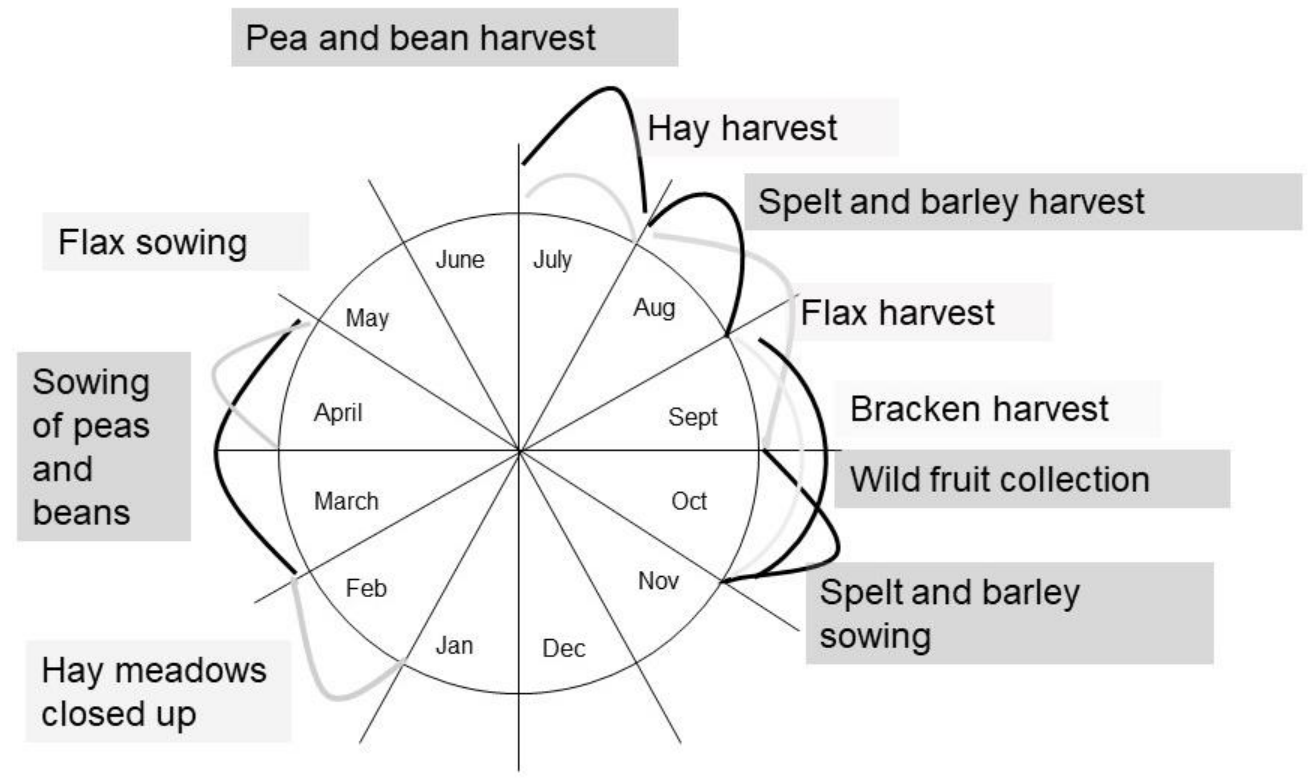

Figure 5: Ecological-temporalities of plants and people at late Iron Age and early Roman Silchester. 
Now that the effectiveness of plants on seasonal labour patterns has been identified at Silchester, we can consider the social and economic values which may have been contested through these overlapping ecological temporalities (Brice, 2014: 951). The annual cycles of human-plant engagements have been visualised in figure 5. During the late Iron Age period at Silchester, there would have been periods of intense labour demands, in autumn as crops were sown and wild plants were collected, in spring as further crops required sowing, and then at harvest time in July. In the late Iron Age and early Roman period, the additions of haymaking and bracken harvesting would have increased the intensity of activity in spring and late summer.

By considering the precise changes in the appearance of plants, the intensity and stress of these periods comes to the fore, whereby human action was governed by the shifting materialities of growing plants. Previous considerations of the social significance of planthuman interactions at Insula IX have focussed upon the harvest period (Fulford et al., 2018: 376), but the consideration of plant agencies throughout the year has shown the multiple and overlapping periods of engagements with plants, governed by the physical changes in plants. These experiences and emotions would have been shared across communities of households, with routine farming practices being carried out as communal groups, and the repeated actions reinforcing shared identities. Whilst the agencies of plants would have acted upon individuals, the collaboration of farmers through plant cultivation, especially a more extensive form of cereal cultivation as indicated by weed ecology analysis (Lodwick, 2018), would strengthen social bonds between those engaged in the same activity. The consistency of archaeobotanical samples across the excavated area of Insula IX implies common practice and seasonal labour engagements within a group of households.

The rural nature of these agricultural engagements is contra to the insights provided from ceramic and faunal evidence from the region around the oppidum at Colchester (Camulodunum) which showed a strong urban-rural divide in consumption practices (Perring and Pitts 2013), a division also indicated by artefactual and faunal evidence for consumption practices from late Iron Age Silchester (Fulford and Timby 2000: 545-564). This contrast may in part arise from different community groups being resident within different areas of oppida, for instance with the suggestion that agriculture was undertaken at Silchester by people previously living in the surrounding region (Creighton with Fry 2016: 368). Furthermore, it shows the importance of considering a variety of social practices in the past to inform upon community organisation, rather than those more immediately visible in the archaeological record.

The similarity in archaeobotanical samples between Periods 0 and 1 (Table 1) evidence continuity in engagements with plants across the late Iron Age-Roman transition in this area of Silchester. This pattern complements the emerging archaeological picture. Whilst the Claudian conquest had an immediate impact with new building projects in the central area of the forum basilica, and perhaps to the west in Insula III (Creighton with Fry 2016: 434-437; Fulford 2008) excavations have revealed continuity in the character and organisation of settlement within Insula IX (Fulford et al. 2012: 5-7). Beyond c. AD60/61, there is little evidence for regular engagements between people and plants. Charred crop-processing waste occurs very rarely from the second century A.D. onwards at Insula IX (Robinson, 2011; Robinson et al., 2006), suggesting the urban community was no longer engaged in crop agriculture. Evidence for the activities of hay meadow management, flax cultivation and bracken collection is rare. The decline in the evidence for crop cultivation and processing by the inhabitants of the town indicates that the ecological temporalities experienced by the residents changed. This changing experience of temporality and seasonality may have contributed to the fragmentation of suprahousehold groups as social bonds beyond the kin group were no longer reinforced on a daily basis. 


\section{Ecological temporality at other oppida}

Expanding this study of plant-human relations to other oppida is constrained due to the rarity of waterlogged plant remains which are often the only form of evidence for many of the humanplant interactions beyond cereals. Limited sampling and reporting at sites also means information on chaff and weed seeds, which combine the temporally distinct activities of crop husbandry and processing, are absent (Lodwick 2018). However, a similar pattern of ecological temporalities is recognisable at the oppidum at Stanwick, North Yorkshire, where the charred plant assemblage was dominated by spelt fine-sieving by-products. Furthermore, the occurrence of grassland and heathland material at Insula IX was mirrored at Stanwick, where Calluna vulgaris (heather) leaf shoots and flowers and Erica sp. (heath) flowers, interpreted as evidence for bedding or thatch, were quite common (Van der Veen, 2016). Where available, archaeobotanical traces of plant-human interactions support the overlapping ecological temporalities observed at Silchester.

Indications of agricultural activity are also present at a number of other oppida in Britain. At Bagendon areas of occupation, banjo enclosures and linears have been characterised as a poly-focal settlement. Stock movement has been suggested as a major function of this settlement (Moore 2012: 411), and seasonality of activities has been inferred, but here on the basis of grain-impressions in coin moulds (Moore 2012: 410). Recently, the agricultural practices evident at the territorial oppidum at Chichester have been emphasized, on the basis of the presence of Mid- and Late Iron Age farmsteads and field systems within the area of the Chichester entrenchments (Garland 2017: 209). At Camulodunum excavations and aerial survey have demonstrated a mixed agricultural landscape in the area around The Gosbecks (Gascoyne and Radford 2013: 47-52). Whilst some of the agricultural practices evidenced at Silchester can be considered as novel in the context of Iron Age Britain (Lodwick 2017a), evidence from other oppida in Britain does at least show that a re-consideration of agriculture indicates that crop and animal-based farming was a part of daily life at many of these settlements. Whilst the ecological temporalities and annual rhythms of social interaction cannot be assessed without archaeobotanical information, it is likely that supra-household groupings negotiated through agricultural activity were important at many of these sites. The character of agricultural practice at continental oppida has recently received renewed consideration (Danielisová and Hajnalová 2014) and expanding such an approach to continental sites with growing archaeobotanical datasets will shed light on the different forms of communities resident within oppida more broadly.

\section{Conclusion}

While research has continued to focus on the articulation of hierarchical power in oppida, consideration of the wider organisation of oppida communities remain neglected. The social significance of agricultural-type settlements within oppida has here served as a starting point for considering the importance of farming practices at the oppidum of Calleva Atrebatum. By recognising the specific form of agency of plants, and their affect upon people through ecological temporalities, a nuanced picture emerges of the multiple cycles of plant-human interactions throughout the year, as experienced through the distinctive characteristics of plants enacted upon humans. Thus the activity of plant husbandry, previously overlooked within social practice approaches, emerges as an area of study, informed upon by the botanical characteristics of plants identified through archaeological evidence, and historical and ethnographic observations of human activities with them.

Rather than a harmonious period of cultivation, followed by a single period of activity at harvest time, the exploration of the ecological temporalities represented by the archaeobotanical assemblage from Silchester has shown multiple interaction with different plants such as flax, spelt, bracken and hay-meadows. The demands of crop plants ensured that people living at 
late Iron Age and early Roman Silchester interacted with plants and each other in regular, repeated routines, in the field and in the home. Each would have ensured stressful and intense periods of labour, the temporality of which would have been governed by the shifting materialities of plant bodies. The annual cycles of plants leads to the conclusion that social organisation beyond the household level would have been required, supporting previous conclusions of extended household-based social organisation drawn from the archaeological evidence. (Moore, 2017a). The archaeobotanical evidence utilised here is commonly available, and when re-situated within a framework of plant agency and ecological temporality, can provide crucial new insights into the social significance of human-plant interactions.

\section{Acknowledgements}

Andrew Gardner provided comments on the text and Jasmine Nirody provided assistance with images.

Many thanks to the directors of the Silchester Insula IX 'Town Life' Project, Mike Fulford and Amanda Clarke. I am grateful to the comments of the anonymous reviewers.

\section{Declaration of Conflicting Interests}

The author(s) declared no potential conflicts of interest with respect to the research, authorship, and/or publication of this article.

\section{Funding}

This research was undertaken in part during an AHRC funded doctoral research project (Grant number $\mathrm{AH} / \mathrm{I01215X/1)}$ at the University of Oxford, and during positions at the University of Reading and University of Oxford. The Silchester Projects received funding from The Calleva Foundation.

\section{References}

Albarella U (2007) The end of the sheep age: people and animals in the late Iron Age. In: Haselgrove $\mathrm{C}$ and Moore $\mathrm{T}$ (eds) The Later Iron Age in Britain and Beyond. Oxford: Oxbow Books, pp. 393-406.

Andresen ST and Karg S (2011) Retting pits for textile fibre plants at Danish prehistoric sites dated between 800 B.C. and A.D. 1050. Vegetation History and Archaeobotany 20(6): 517526.

Baumann G (1986) National Integration and Local Integrity. The Miri of the Nuba Mountains in the Sudan. Oxford: Clarendon Press.

Bogaard A, Krause R and Strien H-C (2011) Towards a social geography of cultivation and plant use in an early farming community: Vaihingen an der Enz, south-west Germany. Antiquity 85: 395-416.

Bond JM and Hunter JR (1987) Flax-growing in Orkney from the Norse period to the 18th century. Proceedings of the Society of Antiquaries Scotland 117: 175-181.

Brice $\mathrm{J}$ (2014) Attending to grape vines: perceptual practices, planty agencies and multiple temporalities in Australian viticulture. Social \& Cultural Geography 15: 942-965. 
Bryant S (2007) Central places or special places? The origins and development of 'oppida' in Hertfordshire. In Haselgrove C and Moore T (eds) The Later Iron Age in Britain and Beyond. Oxford: Oxbow, pp. 62-80.

Campbell G (2000) Plant utilization: the evidence from charred plant remains. In: Cunliffe B The Danebury Environs Programme. The Prehistory of a Wessex Landscape. Oxford: Institute of Archaeology, pp. 45-59.

Campbell G and Hamilton J (2000) Danebury environs: agricultural change in the Iron Age. In: Bailey G, Charles R and Winder N (eds) Human Ecodynamics: Proceedings of the Association for Environmental Archaeology Conference 1998 held at the University of Newcastle upon Tyne. Oxford: Oxbow, pp. 114-122.

Chadwick AM (2004) "Heavier burdens for willing shoulders?" Writing different histories, humanities and social practices for the Romano-British countryside. In: Croxford B, Eckardt $\mathrm{H}$, Meade J, et al. (eds) TRAC 2003: Proceedings of the Thirteenth Annual Theoretical Roman Archaeology Conference. Oxford: Oxbow Books, pp. 90-110.

Chadwick AM (2016) Foot-fall and hoof-hit. Agencies, movements, and materialities; and later prehistoric and Roman-British trackways. Cambridge Archaeological Journal 26(1): 93-120.

Collis J (2000) "Celtic" oppida. In: Hansen M (ed.) A Comparative Study of Thirty City-State Cultures: An Investigation Conducted by the Copenhagen Polis Centre. Copenhagen: Kongelige dansk videnskabernes selskab, pp. 229-239.

Creighton J (2000) Coins and Power in Late Iron Age Britain. Cambridge: Cambridge University Press.

Creighton J (2006) Britannia: the Creation of a Roman Province. Cambridge: Cambridge University Press.

Creighton J with Fry R (2016) Silchester: Changing Visions of a Roman Town. London: Society for the Promotion of Roman Studies.

Cunliffe B (1976) The origins of urbanisation in Britain. In: Cunliffe B and Rowley T (eds) Oppida: the Beginnings of Urbanisation in Barbarian Europe. Oxford: British Archaeological Reports, pp. 135-161.

Cunliffe B (2005) Iron Age Communities in Britain. Abingdon: Routledge.

Danielisová A. and Hajnalová M (2014) Oppida and agricultural production - state of the art and prospects: Case study from the Staré Hradisko oppidum (Czech Republic). In: Hornung $\mathrm{S}$ (ed.) Produktion, Distribution, Ökonomie: Siedlungs- und Wirtschaftsmuster der Latènezeit. Bonn: Halbert Verlag, pp. 407-428.

Eckardt H (2015) Objects and Identities: Roman Britain and the North-Western Provinces. Oxford: O.U.P.

Ertuğ $F$ (2010) Linseed oil and oil mills in central Turkey: Flax/Linum and Eruca, important oil plants of Anatolia. Anatolian Studies 50: 171-185. 
Fernández-Götz M (2014) Reassessing the oppida: the role of power and religion. Oxford Journal of Archaeology 33(4): 379-394.

Fernández-Götz M (2018) Urbanization in Iron Age Europe: trajectories, patterns, and social dynamics. Journal of Archaeological Research 26(2): 117-162.

Fitzpatrick AP (2001) Cross-channel exchange, Hengistbury Head, and the end of hillforts. In: Collis J (ed.) Society and Settlement in Iron Age Europe. Sheffield: J.R. Collis Publications, pp. 82-97.

Fulford M (2008) Nero and Britain: The palace of the client King at Calleva and imperial policy towards the province after Boudicca. Britannia 39: 1-13.

Fulford M, Barnett C, Pankhurst N, et al. (2017) The Silchester Environs Project Excavation and Survey 2017. Reading: University of Reading.

Fulford M, Clarke A, Durham E, et al. (2018) Late Iron Age Calleva: The Pre-Conquest Occupation At Silchester Insula IX. Silchester Roman Town: The Insula IX Town Life Project: Volume 3. London: Society for the Promotion of Roman Studies.

Fulford M, Clarke A, Pankhurst N, et al. (2012) Silchester Insula IX: The 'Town Life' Project 2012. Reading: University of Reading.

Fulford M. and Timby J (2000) Late Iron Age and Roman Silchester: Excavations on the Site of the Forum Basilica, 1977, 1980-86. London: Society for the Promotion of Roman Studies.

Gardner A (2002) Social identity and the duality of structure in late Roman-period Britain. Journal of Social Archaeology 2(3): 323-351.

Gardner A (2007) An Archaeology of Identity: Soldiers and Society in Late Roman Britain. Walnut Creek: Left Coast Press.

Gardner A (2012) Time and empire in the Roman world. Journal of Social Archaeology 12(2): $145-166$.

Garland N (2017) Territorial Oppida and the Transformation of Landscape and Society in south-eastern Britain from BC 300 to 100 AD. Unpublished doctoral thesis, UCL.

Garrow D (2010) The temporality of materials: occupation practices in eastern England during the 5th and 4th millennia BC. In: Finlayson B and Warren G (eds) Landscapes in Transition: Understanding Hunter-Gatherer and Farming Landscapes in the Early Holocene of Europe and the Levant. Oxford: Oxbow, pp. 208-218.

Gascoyne A, Radford D, Crummy P et al. (2013) Colchester, Fortress of the War God: an Archaeological Assessment. Oxford: Oxbow.

Giles M (2007) Good fences make good neighbours? Exploring the ladder enclosures of later prehistoric East Yorkshire. In: Haselgrove C and Moore T (eds) The Later Iron Age in Britain and Beyond. Oxford: Oxbow, pp. 235-249.

Greig J (1984) The palaeoecology of some British hay meadow types. In: van Zeist W and Casparie WA (eds) Plants and Ancient Man: Studies in Palaeoethnobotany. Rotterdam: A.A. Balkema, pp. 213-226. 
Hall M (2011) Plants as Persons: a Philosophical Botany. Albany: State University of New York Press.

Hartley D (2012) Lost World: England 1933-1936: Dispatches to the Daily Sketch. Totnes: Prospect.

Haselgrove C (1982) Wealth, prestige and power: the dynamics of Late Iron Age political centralization in south-east England. In: Renfrew C and Shennan S (eds) Ranking, Resource and Exchange. Cambridge: Cambridge University Press, pp. 79-88.

Haselgrove C (2000) The character of oppida in Iron Age Britain. In: Guichard V, Sievers S and Urban $\mathrm{O}$ (eds) Les Processus d'Urbanisation à L'Âge du Fer: Actes du Colloque Glux-enGlenne, 8-11 Juin 1998 (Glux-en-Glenne). Glux-en-Glenne: Centre archéologique européen du Mont Beuvray, pp. 103-110.

Haselgrove $C$ (2007) The age of enclosure: Later Iron Age settlement and society in northern France. In: Haselgrove C and Moore T (eds) The Later Iron Age in Britain and Beyond.

Oxford: Oxbow Books, pp. 492-522.

Haselgrove C and Millett M (1997) Verlamion reconsidered. In: Gwilt A and Haselgrove C (eds) Reconstructing Iron Age Societies. Oxford: Oxbow Books, pp. 282-296.

Head L and Atchison J (2009) Cultural ecology: emerging human-plant geographies. Progress in Human Geography 33(2): 236-245.

Head L, Atchison J and Phillips C (2015) The distinctive capacities of plants: re-thinking differences via invasive species. Transactions of the Institute of British Geographers 40(3): 399-413.

Hill JD (2011) How did British Middle and Late Pre-Roman Iron Age societies work (if they did)? In: Moore T and Armada X (eds) Atlantic Europe in the First Millennium BC: Crossing the Divide. Oxford: O.U.P, pp. 242-263.

Hill JD (1995) The Pre-Roman Iron Age in Britain and Ireland (ca. 800 B.C. to A.D. 100): an overview. Journal of World Prehistory 9(1): 47-98.

Hill JD (2007) The dynamics of social change in Later Iron Age eastern and south-eastern England c. 300 BC-AD 43. In: Haselgrove C and Moore T (eds) The Later Iron Age in Britain and Beyond. Oxford: Oxbow Books, pp. 16-40.

Hillman G (1981) Reconstructing crop husbandry practices from charred remains of crops. In: Mercer R (ed.) Farming Practice in British Prehistory. Edinburgh: Edinburgh University Press, pp. 123-162.

Ingold T (2000) The Perception of the Environment: Essays in Livelihood, Dwelling and Skill. London: Routledge.

Jones M (2007) A feast of Beltain? Reflections on the rich Danebury harvests. In: Gosden C, Hamerow $\mathrm{H}$, de Jersey $\mathrm{P}$, et al. (eds) Communities and Connections: Essays in Honour of Barry Cunliffe. Oxford: O.U.P., pp. 142-153. 
Jones $O$ (2011) Materiality and identity - forests, trees and senses of belonging. In Ritter E and Dauksta D (eds) New Perspectives on People and Forests. Dordrecht: Springer Netherlands, pp. 159-177.

Jones $\mathrm{O}$ and Cloke $\mathrm{P}$ (2008) Non-human agencies: Trees in place and time. In: Knappett $\mathrm{C}$ and Malafouris L (eds) Material Agency: Towards a Non-Anthropocentric Approach.

Dusselford: Springer, pp. 79-96.

Jones W (1938) Pliny the Elder: Natural History. Loeb Classical Library.

Lambrick G and Robinson M (2009) The Thames Through Time: The Archaeology of the Gravel Terraces of the Upper and Middle Thames: The Thames Valley in Late Prehistory, $1500 B C-A D$ 50. Oxford: Oxford University School of Archaeology.

Lodwick LA (2017a) Agricultural innovations at a Late Iron Age oppidum: Archaeobotanical evidence for flax, food and fodder from Calleva Atrebatum, UK. Quaternary International 460: 198-219.

Lodwick L (2017b) Arable farming, plant foods, and resources. In: Allen M, Lodwick L, Brindle T, et al. The Rural Economy of Roman Britain: Farming, Industry, Transport and Markets. London: Society for the Promotion of Roman Studies, pp. 11-84.

Lodwick $L$ (2018) The charred and waterlogged plant remains. In: Fulford M, Clarke A, Durham E, et al. Late Iron Age Calleva: The Pre-Conquest Occupation at Silchester Insula IX. Silchester Roman Town: The Insula IX Town Life Project: Volume 3. London: Society for the Promotion of Roman Studies, pp. 285-313.

Mabey R (1996) Flora Britannica. London: Sinclair-Stevenson.

Marrs RH and Watt AS (2006) Biological flora of the British isles: Pteridium aquilinum (L.) Kuhn. Journal of Ecology 94: 1272-1321.

Moore T (2012) Beyond the oppida: polyfocal complexes and Late Iron Age societies in southern Britain. Oxford Journal of Archaeology 31(4): 391-417.

Moore T (2017a) Alternatives to urbanism? Reconsidering oppida and the urban question in Late Iron Age Europe. Journal of World Prehistory 30(3): 281-300.

Moore T (2017b) Beyond Iron Age "towns": examining oppida as examples of low-density urbanism. Oxford Journal of Archaeology 36(3): 287-305.

Murphy P (1977) Early Agriculture and Environment on the Hampshire Chalklands: circa. 800 B.C. - 400 A.D. Unpublished MPhil thesis, University of Southampton, UK.

Pitts M (2010) Re-thinking the southern British oppida: networks, kingdoms and material culture. European Journal of Archaeology 13(1): 32-63.

Pitts M and Perring P (2013) Alien cities. Consumption and the Origins of Urbanism in Roman Britain, London. Portslade: Spoilheap Monograph 4.

Pitts M and Perring D (2006) The making of Britain's first urban landscapes: the case of Late Iron Age and Roman Essex. Britannia 37: 189-212. 
Rees S (2011) Agriculture. In: Allason-Jones L (ed.) Artefacts in Roman Britain: Their Purpose and Use. Cambridge: Cambridge University Press, pp. 89-113.

Ribeiro A (2016) Against object agency. A counterreaction to Sorensen's 'Hammers and nails'. Archaeological Dialogues 23(2): 229-235.

Robinson M (2011) The macroscopic plant and invertebrate remains. In: Fulford M and Clarke A Silchester: City in Transition: the Mid-Roman Occupation of Insula IX C. A.D. 125-250/300: a Report on Excavations Undertaken Since 1997. London: Society for the Promotion of Roman Studies, pp. 281-293.

Robinson M, Fulford N and Tootell K (2006) Macroscopic plant remains. In: Fulford M, Clarke $\mathrm{A}$ and Eckardt $\mathrm{H}$ Life and Labour in Late Roman Silchester: Excavations in Insula IX since 1997. London: Society for the Promotion of Roman Studies, pp. 206-218.

Rymer $L$ (1976) The history and ethnobotany of bracken. Botanical Journal of the Linnean Society 73: 151-176.

Sharples N (2010) Social Relations in Later Prehistory: Wessex in the First Millennium BC. Oxford: O.U.P.

Slicher van Bath BH (1963) The Agrarian History of Western Europe, AD 500-1850. London: Edward Arnold.

Smith ME (2016) How can archaeologists identify early cities: definitions, types, and attributes. In: Fernández-Götz M and Krausse D (eds) Eurasia at the Dawn of History: Urbanization and Social Change. Cambridge: Cambridge University Press, pp. 153-168.

Stevens C (2003) An investigation of agricultural consumption and production models for prehistoric and Roman Britain. Environmental Archaeology 8(1): 61-76.

Stoddart S (2017) Introduction. In: Stoddart S (ed.) Delicate Urbanism in Context: Settlement Nucleation in Pre-Roman Germany. Cambridge: McDonald Institute for Archaeological Research, pp. 1-5.

Styring AK, Charles M, Fantone F, et al. (2017a) Isotope evidence for agricultural extensification reveals how the world's first cities were fed. Nature Plants 3: 17076.

Styring A, Rösch M, Stephan E, et al. (2017b) Centralisation and long-term change in farming regimes: comparing agricultural practices in Neolithic and Iron Age south-west Germany. Proceedings of the Prehistoric Society 83: 357-381.

Swift C (2002) Celts, Romans and the Coligny calendar. In: Carruthers M, Van Driel-Murray C, Gardner A, et al. (eds) TRAC 2001: Proceedings of the Eleventh Annual Theoretical Roman Archaeology Conference. Oxford: Oxbow, pp. 83-95.

Taylor B (2018) Subsistence, environment and Mesolithic landscape archaeology. Cambridge Archaeological Journal 28(3): 493-510.

Taylor J (2013) Encountering Romanitas: characterising the role of agricultural communities in Roman Britain. Britannia 44: 171-190. 
University of Reading (2018) Late Iron Age Calleva: The Pre-Conquest Occupation at Silchester Insula IX [data-set]. Archaeology Data Service, York. DOI:

https://doi.org/10.5284/1046734

Van der Veen M (2014) The materiality of plants: plant-people entanglements. World Archaeology 46(5): 799-812.

Van der Veen M (2016) The arable economy. In: Haselgrove C Cartimandua's Capital? The Late Iron Age Royal Site at Stanwick, North Yorkshire, Fieldwork and Analysis 1981-2011. York: Council for British Archaeology, pp. 287-303.

Van Driel-Murray C (2002) Regarding the stars. In: Carruthers M, Van Driel-Murray C, Gardner A, et al. (eds) TRAC 2001: Proceedings of the Eleventh Annual Theoretical Roman Archaeology Conference Glasgow 2001. Oxford: Oxbow, pp. 96-103.

Williams M (2003) Growing metaphors: the agricultural cycle as metaphor in the Later Prehistoric period of Britain and north-western Europe. Journal of Social Archaeology 3(2): 223-255. 